\title{
CORPORATE GOVERNANCE MECHANISMS AND PERFORMANCE IN AIR MANAGEMENT COMPANIES: A fSQCA APPROACH
}

\author{
GIOVANNI OSSOLA, GUIDO GIOVANDO, AND CHIARA CROVINI \\ Department of Management, University of Torino, Torino, Italy
}

\begin{abstract}
This article examines the role of governance mechanisms and economic variables in financial performance of air management companies in Italy. The research draws on corporate governance theory, stakeholder theory, and performance analysis in the airport industry. Fuzzy-set qualitative comparative analysis (QCA) was used to analyze a sample of Italian air management companies. Data were extracted from AIDA database, public reports, and corporate governance documents. Results confirm that different combinations of governance mechanisms, number of passengers, and number of employees can yield similar financial performance. This research also identifies the most significant items that can impact the financial performance, and the relationships among governance mechanisms, and financial performance of those companies.
\end{abstract}

Key words: Air management companies; Low-cost transport; Corporate governance; Financial performance; Fuzzy-set qualitative comparative analysis (QCA)

Introduction

Over the past three decades, airline transport has grown in Europe thanks to low-cost airline companies, also playing an important role in the development of tourism (Dogru, Bulut, \& Sirakaya-Turk, 2016; Dogru, Sirakaya-Turk, \& Crouch, 2017; Ekinci, Sirakaya-Turk, \& Baloglu, 2007; Giacosa \& Giovando, 2018). Airports have therefore become pivotal centers for economic growth, culture, and business (Ashford, Mumayiz, \& Wright, 2011), leading to the development of customer satisfaction and commitment (Zhong, Busser, \& Baloglu, 2017). These aspects are directly linked to airport competitiveness (Thelle \& la Cour Sonne, 2018) and can affect air traffic and potential economic benefits (Romero, Lafont, Tafur, \& Eguren, 2016). The selection of airports from airlines, passengers' choices, and the active response from other airports can influence the success of airports. Passengers have multiple options to choose from due to the existence of airports with overlapping areas of influence, thanks to an unprecedented access to more airlines and airport information. 
Consequently, airports are responding and focusing on a wider variety of commercial activities and revenues not related to the aviation business (Romero et al., 2016).

This research fits into this framework and aims to improve past analysis on the performance of air management companies in Italy. The study follows and takes further a research project on the airport infrastructure by Ossola, Giovando, and Crovini $(2015,2018)$, expanding the sample of companies analyzed and considering additional relevant aspects. This analysis is also based on the assumptions and empirical evidence of Romero et al. (2016), who concentrated on the air transport in the UK.

To complement the existing literature, the authors have investigated the impact and causal relationship between number of passengers, type of revenues, and employment rate on the overall performance, measured by the return on assets (ROA). In addition, the study also considers the role of governance mechanisms in improving the financial performance of air management companies in Italy.

No previous research dealing with the effect of the attributes implied in this study exists.

Moreover, a novel methodological approach called fuzzy-set qualitative comparative analysis (fsQCA) was used to develop the research model and test the causal relationships among variables and outcome. The fsQCA approach is fundamental for theory testing, and for concept formation, elaboration, refinement, and theory development (Fiss, 2011).

Consequently, this article represents a multidisciplinary study as the interest towards the development of low-cost airlines has important consequences and enhances the relationship with the territory in which the air management company operates.

This article is organized as follows. Section 2 presents the theoretical background and the research model. Section 3 describes the fsQCA methodology, sample, and attributes. Section 4 shows results and Section 5 presents the discussion. Section 6 offers the conclusions, main implications, limitations, and future developments of the application of QCA in air management companies.
Theoretical Background and Research Model

\section{The Airport Industry}

In recent decades, airport services have been liberalized at various levels in all countries (Forsyth, 2002; Romero et al., 2016). This liberalization broke monopolies and created a more competitive system with an ever-increasing development (Gillen, 2011; Pulina \& Cortés-Jiménez, 2010; Romero et al., 2016; Thelle \& la Cour Sonne, 2018).

An important change in the sector was marked by deregulation, leading to the emergence and growth of new airlines, among which were low-cost airlines (Morrell, 2008; Morrison \& Winston, 1995). This phenomenon consistently increased the air traffic transport, in terms of number of passengers, and led to the development of the sector in general.

With particular reference to airport management companies, strategic behavior was examined after deregulation (Bruni, 2004; Kleymann \& Seristo, 2004), as well as the business model of such enterprises (Kasarda, 2006; Ossola, Giovando, \& Crovini, 2016). In addition, scholars concentrated on the impact of privatization on airport ownership structure and related performance (Gillen, 2011; Oliveira Cruz \& Sarmento, 2017; Usami \& Akai, 2012; Vogel, 2006).

Ahn and Lee (2011) focused on service quality in the airline industry from the customer's perspective, exploring how perceived service quality affects customer satisfaction and loyalty-related behavior and whether factors affecting service quality, customer satisfaction, and loyalty differ between full-service and low-cost airlines.

The increasing importance of market orientation and airport marketing in airport management led to the inclusion of these aspects in the analysis of the alternative revenue sources of airports (Graham, 2008). Larger airports are normally in a better position to provide a greater range of commercial facilities for passengers and other consumers, and therefore tend to benefit from nonaeronautical revenues. Current business models should consider the potential effect of nonaeronautical aspects and other commercial activities (Kasarda, 2006). Advertising and park lots are the most common processes of diversification. Many airports get a large part of their income from these sources and, in some cases, that income is still greater than that which comes from aviation 
(Kasarda, 2006). For example, Atlanta, DallasFort Worth (DFW), Hong Kong, and Schiphol airports have two thirds of their income come from nonaeronautical activities (Ashford et al., 2011).

The analysis of sales growth is generally seen as an opportunity to enhance future performance (Curi, Gitto, \& Mancuso, 2010; La Porta, Lopezde-Silanes, Shleifer, \& Vishny, 2000). In fact, quantitative analysis of data from the financial statements of airport management companies were carried out to ensure stable and permanent financial results (Gitto \& Mancuso, 2012; Lai, Potter, \& Beynon, 2012; Oum, Yan, \& Yu, 2008; Oum, Yu, \& Fu, 2003; Teodori, Carini, \& Falini, 2006; Tsekeris, 2011; Wang, Lu, \& Tsai, 2011).

With business model changes of air management companies (Ossola et al., 2016; Wang et al., 2011) revenues from nonaviation activities have increased. These nonaviation activities refer to a wide range of commercial services for passengers, operators and visitors, such as parking lots, shops, restaurants, and publicity (Gitto \& Mancuso, 2012; Tsekeris, 2011). Core activities instead refer to those supporting passenger and freight aviation, including revenues from airport fees, handling, and security management activities.

Therefore, to analyze performance and efficiency of air management companies, it is necessary to consider the following propositions:

Proposition 1: Aviation and nonaviation revenues of air management companies, after increasing their importance with changes in the business model, lead to strong financial performance of air management companies.

Proposition 2: The number of low-cost passengers directly and positively influences the financial performance of air management companies.

Studies on corporate governance refer to "the set of mechanisms that influence the decisions made by managers when there is a separation between ownership and control" (Larcker, Richardson, \& Tuna, 2007, p. 964; see also Felício, Rodrigues, $\&$ Samaiago, 2016). Research on corporate governance "examine whether different corporate governance structures impact or limit the behavior of executives and/or have an impact on organizational performance" (Larcker et al., 2007, p. 964).
Corporate governance studies typically consider agency theory to describe the relationship between shareholders and managers (Finegold, Benson, \& Hecht, 2007; Renders \& Gaeremynck, 2012). Due to the wide range of company sizes within the sample set, this study bases the conceptualization on stakeholder theory (Freeman, 1984).

Previous research analyzed the role of governance mechanisms and performance of airline companies (Wang et al., 2011).

Board size is beneficial as it makes expertise and resources more readily accessible to firms (Dalton, Daily, Johnson, \& Ellstrand, 1999; Felício et al., 2016). Nonetheless, other authors argue that large boards impair firm performance (Hermalin \& Weisbach, 2003) as it is more difficult to effectively monitor the management. Larger boards offer greater opportunities for shirking and delay decision making (Jensen, 1993).

Proposition 3: Large boards increase the financial performance of air management companies.

As regards the topic of affiliated directors, Van Essen, Engelen, and Carney (2013) reported the importance of directors' independence, claiming that clear separation between directors and insiders or major shareholders ensures that former can independently assess the management. This independence is also linked to the committees within the board of directors. Affiliated directors may be under the influence of the top executives and the overall management can suffer from potential conflicts of interests (Felício et al., 2016).

Proposition 4: The absence of affiliated directors enhances the financial performance of air management companies.

In the airport sector, many scholars focused on the government participation in airport management companies in several countries (Graham, 2008; Oum et al., 2008; Romero et al., 2016; Usami \& Akai, 2012).

In addition, over the past few years the topic of gender diversity has been extensively studied by considering cross-country analysis and the development of regulations (Iannotta, Gatti, \& Huse, 2015; Sanan, 2016; Seierstad, Warner-Søderholm, 
Torchia, \& Huse, 2017). Prior research shows that gender diversity can either improve the quality of decisions by introducing new perspectives and enriching the information available or hinder effective team performance by increasing divisiveness and conflicts (Alazzani, Hassanein, \& Al-Janadi, 2017; Alfiero, Cane, De Bernardi, \& Venuti, 2016; Alfiero, Cane, Esposito, \& Doronzo, 2018; Boone \& Hendriks, 2009; Gilbert \& Ivancevich, 2000; Kravitz, 2003). This may be due to the different leadership styles between men and women; in fact, female directors are more participative and democratic than men (Ray, 2005). Landry, Bernardi, and Bosco (2014) found that the higher the percentage of women on a firm's board of directors, the more likely the company is to appear as the most admired, the most ethical, and the best to work for.

Proposition 5: The presence of women in boards leads to strong financial performance in air management companies.

In this research it is interesting to evaluate the causal relationship between size, composition, and functioning of the boards of air management companies and performance, as these corporate governance mechanisms influence financial reporting and performance (Larcker et al., 2007; Wang et al., 2011). The significant relationship between female presence in boards and firm performance was deeply studied by several authors (Iannotta et al., 2015; Sanan, 2016; Seirstad et al., 2015) and can definitely add value to the comparative analysis.

Finally, some researchers highlighted the correlation between local development and the airport structure, which has indirect positive effects on the surrounding areas (Shearman, 1992; Tyrrell \& Johnston, 2002), with an increase in economic activity and positive economic impact (Brueckner, 2003; Button \& Taylor, 2000). Some studies, in particular, focused on the assessment of these effects on individual countries (A. Cooper \& Smith, 2005).

Moreover, researchers started analyzing the correlation between the number of employees, representing the employment rate and the economic performance (Oum et al., 2003). This element was therefore considered in the development of the research model.
Proposition 6: The employment rate, in terms of number of employees, creates value for air management companies, by enhancing the financial performance.

In this study, the authors aim to analyze with a configurational approach the causal relationship between several attributes and the financial performance. Figure 1 summarizes all the propositions tested in this empirical analysis.

\section{The Research Model}

By considering the theoretical background, the authors elaborated different propositions and a research model (Fig. 2) to explore how different combinations of governance factors, financial and economic variables can affect financial performance of the air management companies in Italy. As mentioned above, the governance variables implied in this research are those studied in previous research (Felício et al., 2016; Grove, Patelli, Victoravich, \& Xu, 2011; Larcker et al., 2007; Seierstad et al., 2017; Usami \& Akai, 2012; Wang et al., 2011) and were adapted to air management companies.

The other attributes chosen for this research were based on factors discussed in previous studies conducted on the topic by Romero et al. (2016), Ossola et al. $(2015,2018)$, and Oum et al. (2003). The research model has seven attributes and one

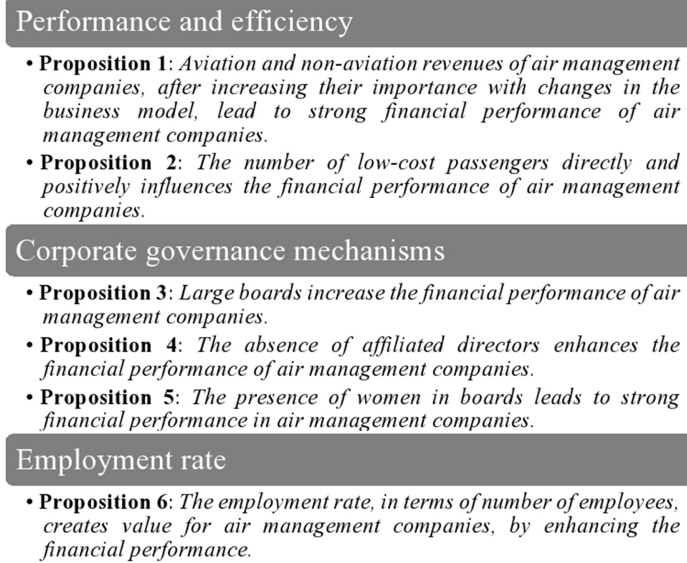

- Proposition 1: Aviation and non-aviation revenues of air management companies, after increasing their importance with changes in the business model, lead to strong financial performance of air management companies

- Proposition 2: The number of low-cost passengers directly and positively influences the financial performance of air management companies.

Corporate governance mechanisms

- Proposition 3: Large boards increase the financial performance of air management companies.

- Proposition 4: The absence of affiliated directors enhances the financial performance of air management companies.

- Proposition 5: The presence of women in boards leads to strong financial performance in air management companies.

Employment rate

- Proposition 6: The employment rate, in terms of number of employees, creates value for air management companies, by enhancing the financial performance.

Figure 1. Propositions tested in the configurational analysis. 


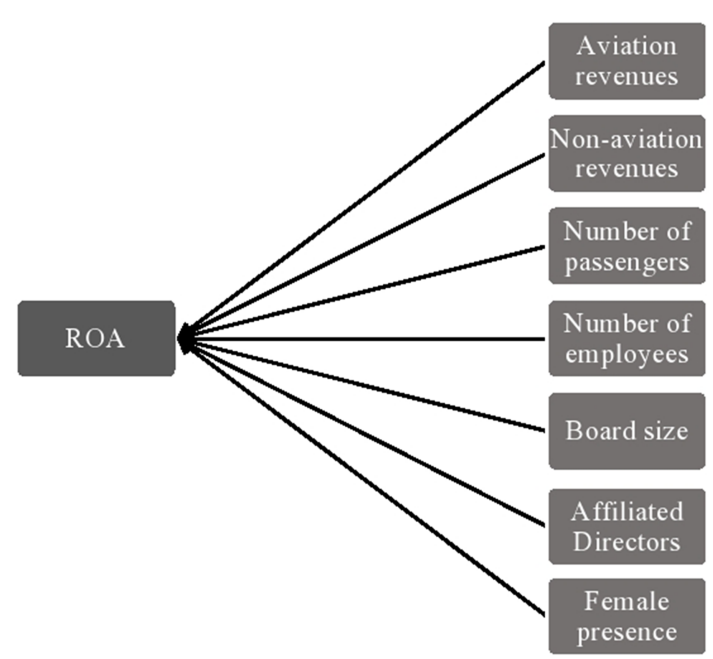

Figure 2. Research model.

outcome (see Fig. 1). The attributes are the number of passengers, aviation revenues, nonaviation revenues, number of employees, board size, affiliated directors, and number of women in boards. The outcome is the financial performance. Table 1 better summarizes all details about the attributes and outcome.

\section{Methodology}

\section{A Qualitative Comparative Approach}

Authors used fuzzy-set QCA (details in Section 4) to identify the causal conditions that lead to good financial performance in air management companies in Italy. This method is particularly helpful to analyze small and medium samples and avoid considering only dichotomized variables.

Over the past few years, scholars have witnessed an increasing curiosity for a method, called QCA, introduced for the first time by the American social scientist Charles Ragin in 1987. Developments of this methodology by Ragin $(2000,2006)$ and Rihoux and Ragin (2008) have contributed to a better applicability of QCA to empirical social scientific research questions leading to its prominence within the discipline. QCA was first introduced as a method for analyzing data sets consisting of binary variables (Ragin, 1987). The basic concept was to constitute

Table 1

Outcome and Attributes

\begin{tabular}{|c|c|}
\hline \multicolumn{2}{|l|}{ Outcome } \\
\hline $\begin{array}{l}\text { Return on Assets } \\
\text { (ROA) }\end{array}$ & $\begin{array}{l}\text { Authors considered only the outcome variable for the year 2016, as proxy for financial perform- } \\
\text { ance (Curi et al., 2010; Teodori et al., 2006). }\end{array}$ \\
\hline \multicolumn{2}{|l|}{ Attributes } \\
\hline $\begin{array}{l}\text { Aviation and nonavia- } \\
\text { tion revenues }\end{array}$ & $\begin{array}{l}\text { The impact on the overall performance of the two strategic business unit may vary from one } \\
\text { airport to another (Curi et al., 2010; Gitto \& Mancuso, 2012; Ossola et al., 2015; Romero et al., } \\
\text { 2016). Therefore, it is particularly interesting to test with a configurational model the effective } \\
\text { causal relationship with the outcome. }\end{array}$ \\
\hline $\begin{array}{l}\text { Number of low-cost } \\
\text { passengers }\end{array}$ & $\begin{array}{l}\text { This attribute is particularly relevant because previous studies demonstrate that there is a strong } \\
\text { relationship with the trend of revenues, EBITDA, and performance (Ossola et al., 2015, 2018; } \\
\text { Usami \& Akai, 2012; Wang et al., 2011). }\end{array}$ \\
\hline Number of employees & $\begin{array}{l}\text { This attribute is considered as a proxy for the development of the local territory in which the air- } \\
\text { port operates. It represents the employment rate and, to further previous analysis (Ossola et al., } \\
\text { 2018; Oum et al., 2003), it is necessary to evaluate the potential impact on the performance that } \\
\text { employees' workforce might have. }\end{array}$ \\
\hline Board size & $\begin{array}{l}\text { Board size comprises the number of members on the compensation committee, the number of } \\
\text { members on the audit committee, and the number of members on the board of directors (Larcker } \\
\text { et al., 2007; Wang et al., 2011). The size of boards and committees may increase diversity, } \\
\text { knowledge, and experience but may hinder coordination. }\end{array}$ \\
\hline Affiliated directors & $\begin{array}{l}\text { Affiliated directors refer to the number of affiliated members of the audit committee, compensa- } \\
\text { tion committee, affiliated audit committee chair, and affiliated compensation committee chair. } \\
\text { This is a dummy variable that equals } 1 \text { if the chairperson was affiliated and } 0 \text { otherwise (Larcker } \\
\text { et al., 2007). Authors assumed that affiliated members were under the influence of the executive } \\
\text { members of the board. }\end{array}$ \\
\hline $\begin{array}{l}\text { Female presence in } \\
\text { boards }\end{array}$ & $\begin{array}{l}\text { Consistent with stakeholder theory, a diversified and independent board may balance a firm's finan- } \\
\text { cial and nonfinancial goals with limited resources and moderate the possible conflicting expecta- } \\
\text { tions of stakeholders, who have disparate interests (Alazzani et al., 2017; Liao et al., 2015). }\end{array}$ \\
\hline
\end{tabular}

Source: Elaborated by the authors. 
such data by Boolean functions. Ragin $(2000,2008)$ expanded the method to allow constructions of fuzzy set relations, by dealing with variables having more than two values, attempting to integrate qualitative and quantitative research methods (Rohwer, 2011).

In addition, fsQCA is suited to addressing equifinality, causal asymmetry, and possible interdependence of input variables ${ }^{1}$ (B. Cooper \& Glaesser, 2015; Greckhamer, Misangyi, Elms, \& Lacey, 2007; Pajunen, 2008; Ragin, 2000, 2008; Woodside, 2010). Each case represents as a combination of causal and outcome conditions (Poveda \& Martínez, 2013). Cases characterize formal logical statements in which the independent variables (conditions) for each case, in combination, logically imply the score on the dependent variable (outcome) for that case. These combinations can be compared with each other and subsequently simplified through a bottom-up process of paired comparison (Poveda \& Martínez, 2013; Ragin, 1987).

The first stage in QCA is to specify the causal conditions for the outcome variable, the financial performance of air management companies.

The next step is to build a truth table with data for selected cases regarding the causal conditions and the outcome variable. Truth tables list the possible combinations of conditions and the outcome associated with each combination (Poveda \& Martínez, 2013). A truth table also elaborates and formalizes the process of examining cases.

The second step consists of the analysis of causal sufficiency of different combinations of factors that meet the specified criteria of sufficiency for the outcome to occur. In particular, the membership score on the outcome is consistently higher than the membership score of the causal combination. This means that the percentage that measures the relevance of each factor explaining the causal relationship on the outcome is generally higher than the overall relevance of the combination of all factors.

Consequently, it emerges that the fsQCA approach is fundamental for theory testing, and for concept formation, elaboration, refinement, and theory development (Fiss, 2011).

\section{Sample, Data Collection, and Calibration}

The research focuses on a sample of Italian airports that entrust their transport services mainly to low-cost airlines. Some of them are considered "secondary" airports, as they are located far away from the city.

This is a systematic or reasoned sample because extraction and identification of elements does not happen randomly (Gambel, 2005; Spiegel, 1994). The sample selection criteria are the following:

- market share greater than $30 \%$;

- number of low-cost passengers over 1 million units per annum.

The sample set was selected based on data provided by ENAC (Ente Nazionale per l'Aviazione Civile), referring to the air traffic in 2016. Authors considered the airports and the related air management companies in Table 2 from this sample set. This sample is representative as it covers the $90 \%$ of low-cost passengers in Italy.

This research also considers the information about the corporate governance and the financial statements of the last accounting year available (2016) of the related air management companies.

Data were extracted from the AIDA database and details regarding revenues and composition of the governance boards were gathered manually from annual reports and documents publicly available on company websites.

Some companies used the Italian accounting principles (OIC) and others instead the IAS-IFRS principles.

The large disparity in company size within the sample set serves the purpose to better test the research model.

fsQCA allows for gradual set membership, thus preserving information though a calibration process (Ricciardi, Zardini, \& Rossignoli, 2018). Calibration involves transforming original data into a continuous value interval from 0 to 1 (Ragin \& Fiss, 2008; Woodside, 2010).

The authors calibrated the original variables and factors by taking the average as the point of maximum ambiguity (cross-over point) and the percentiles 0.05 and 0.95 as the thresholds for full nonmembership and full membership, respectively. After calibration (Crilly, Zollo, \& Hansen, 2012), authors replaced the 0.5 value of maximum ambiguity with 0.499 . Aviation and nonaviation revenues, as well as board size and number 
Table 2

Sample of Analysis

\begin{tabular}{ll}
\hline Air Management Companies & \multicolumn{1}{c}{ Cities/Airports } \\
\hline SACBO Spa & Bergamo \\
SEA Spa & Milano (Malpensa and Linate) \\
Toscana Aeroporti Spa & Pisa \\
Aeroporti di Roma Spa & Roma (Fiumicino and Ciampino) \\
Aeroporto Guglielmo Marconi di Bologna Spa & Bologna \\
Aeroporti di Puglia Spa & Bari, Brindisi and Foggia \\
SOGAER Spa & Cagliari \\
SAC Spa & Catania \\
SACAL Spa & Lamezia Terme \\
GEASAR Spa & Olbia \\
GESAP Spa & Palermo \\
GESAC Spa & Napoli \\
SAGAT Spa & Torino \\
Aeroporto Valerio Catullo di Verona Villafranca Spa & Verona \\
SAVE Spa & Venezia and Treviso \\
\hline
\end{tabular}

Source: Elaborated by the authors on data provided by ENAC (www.enac.it).

of employees were normalized before calibration, by transforming the original values into log values (see Table 3).

The software used in this analysis is fsQCA 2.5 , which provided an output listing the complex, parsimonious, and intermediate solutions. Rihoux and Ragin (2008) argued that the intermediate solution has considerable benefits over the other solutions.

\section{Results}

Different combinations of attributes led to strong financial performance. Based on the attributes, the maximum number of combinations was 128 , although some of these combinations may not have been covered by empirical cases in this sample. The latter represent the logical remainders, excluded from the analysis (Fiss, 2011; Ragin, 2008). The

Table 3

Dataset for fsQCA Analysis

\begin{tabular}{|c|c|c|c|c|c|c|c|c|}
\hline Companies & fs_roa & $\begin{array}{l}\text { Affiliated } \\
\text { Directors } \\
\text { (Dummy) }\end{array}$ & fs_avrev & fs_nonavrev & fs_n.pass & fs_female & fs_emp & fs_board \\
\hline SACBO & 0.44 & 0 & 0.62 & 0.17 & 0.1 & 0.9 & 0.73 & 0.72 \\
\hline SEA & 0.31 & 1 & 0.13 & 0.02 & 0.17 & 0.03 & 0.22 & 0.16 \\
\hline Toscana & 0.74 & 1 & 0.54 & 0.22 & 0.62 & 0.27 & 0.61 & 0.44 \\
\hline AdR & 0.16 & 1 & 0.08 & 0.02 & 0.01 & 0.82 & 0 & 0.75 \\
\hline Bologna & 0.65 & 1 & 0.75 & 0.17 & 0.58 & 0.06 & 0.75 & 0.41 \\
\hline AdP & 0.91 & 0 & 0.76 & 0.12 & 0.53 & 0.95 & 0.81 & 0.96 \\
\hline GESAC & 0.03 & 0 & 0.62 & 0.24 & 0.75 & 0.42 & 0.77 & 0.83 \\
\hline GESAP & 0.95 & 0 & 0.73 & 0.23 & 0.75 & 0.9 & 0.83 & 0.95 \\
\hline SAC & 0.28 & 0 & 0.66 & 0.43 & 0.5 & 0.9 & 0.9 & 0.94 \\
\hline SAVE & 0.31 & 0 & 0.46 & 0.16 & 0.71 & 0.34 & 0.77 & 0.6 \\
\hline SOGAER & 0.48 & 0 & 0.82 & 1 & 0.92 & 0.68 & 0.91 & 0.95 \\
\hline SACAL & 0.97 & 0 & 0.92 & 0.7 & 0.93 & 0.68 & 0.84 & 0.95 \\
\hline GEASAR & 0.05 & 0 & 0.95 & 0.14 & 0.95 & 0.95 & 0.89 & 0.91 \\
\hline SAGAT & 0.41 & 0 & 0.79 & 0.31 & 0.91 & 0.9 & 0.87 & 0.86 \\
\hline Aeroporto Valerio Catullo di Verona Villafranca & 0.91 & 0 & 0.87 & 0.46 & 0.95 & 0.82 & 0.94 & 0.89 \\
\hline
\end{tabular}

Source: Elaborated by the authors through fsQCA software 2.5. 
results also confirm the presence (or absence) of core and peripheral conditions in the combinations that led to the outcomes.

Table 4 reports the solutions. As suggested by Ragin (1987), authors decided not to represent the same results by using quantitative methods to avoid confusion. Results show the equifinality of first-order (or across-type) and second-order (or within-type) solutions. The overall solution coverage was 1 and the solution consistency was $0.76^{2}$. These data are related to the small sample of cases implied in the analysis and demonstrate the perfect adaptability of the theoretical model and related considerations to the air management companies analyzed. However, coverage results also indicate that there could be other possible solutions impacting the financial performance of those companies.

In all solutions, the core causal condition represented by aviation revenues is present and impacts directly on the financial performance. Interestingly, nonaviation revenues are only determinant in solution B. Consequently, core activities represent one of the most influential factors impacting the performance of air management companies, while revenues deriving from other business areas are not particularly relevant financially and economically.

As regards governance attributes, board size is relevant and directly impacts on the outcome in solution $\mathrm{B}$ and $\mathrm{C}$. This means that larger boards have

Table 4

Configurations Leading to Strong Financial Performance in Air Management Companies in Italy

\begin{tabular}{lccc}
\hline & \multicolumn{3}{c}{ Solutions } \\
\cline { 2 - 4 } & A & B & C \\
\hline Aviation Revenues & $\bullet$ & $\bullet$ & $\bullet$ \\
Nonaviation revenues & $\bigcirc$ & $\bullet$ & $\bigcirc$ \\
No. passengers & $\bullet$ & $\bullet$ & \\
No. employees & $\bullet$ & $\bullet$ & $\bullet$ \\
Board size & $\circ$ & $\bullet$ & $\circ$ \\
Affiliated directors & $\bullet$ & $\circ$ & $\bullet$ \\
Female in boards & $\circ$ & $\bullet$ & \\
Consistency & 1 & 0.816901 & 0.765151 \\
Raw coverage & 1 & 0.654255 & 0.500000 \\
Unique coverage & 1 & 0.715116 & 0.525424 \\
Overall solution coverage & 1 & & \\
Overall solution consistency & 0.765151 & & \\
\hline
\end{tabular}

Note. $\bullet$ core causal condition present; $\bullet$ peripheral causal condition present; $\bigcirc$ core causal condition absent; $\circ$ peripheral causal condition absent. a huge impact on the financial performance of these companies. The gender of board members instead does not influence the performance in solution A. Moreover, the presence of affiliated directors is a peripheral condition that only affects solution A.

In addition, the solutions confirm the fact that the more employees the air management companies have, the more they impact on the outcome. But, interestingly, in solution $\mathrm{C}$ the number of passengers is not influential. This represents a particular combination considering that in solution $\mathrm{C}$ the aviation revenues have a huge impact on the financial performance. Therefore, we expected that this factor was influential in all solutions.

\section{Discussion}

The results highlight the importance of the diversification of the revenues into aviation and nonaviation activities. Both are relevant in determining a strong financial performance in solution $\mathrm{B}$, confirming the results of previous studies conducted on this topic (Gitto \& Macuso, 2012; Ossola, 2015, 2018). The other two solutions instead show minor influence of nonaeronautical activities on the return on assets of the Italian air management companies. Both cases suggest the partial validity of Proposition 1.

Corporate governance attributes instead are fundamental to achieve and ensuring financial performance. However, findings underline that effects vary according to the context and complementarities between attributes. In fact, some air management companies (the nonlisted ones) do not present internal committees in the board of directors; therefore, in solutions B and C the condition of affiliated directors is not present. Affiliated directors should be aligned with managers, and their existence may increase agency problems. Financial performance should therefore benefit from the absence of affiliated directors (Felíco et al., 2016). Consequently, Proposition 4 can be partially confirmed by solutions $\mathrm{B}$ and $\mathrm{C}$.

The same goes for the gender diversity: the nonlisted air management companies are not obliged to have women on the boards. Solution A discounts entirely the attribute female presence in the board as an indicator for strong financial performance. Within the parameters of the study, the presence of women in boards does not appear to affect the 
financial performance (Alazzani et al., 2017), partially refuting Proposition 5 .

As regards board size, Proposition 3 can be partially confirmed. This research shows that air management companies achieve strong performance when large boards and committees are present, thereby opposing the idea that it is more difficult to coordinate large boards and committees (Proposition 3 is confirmed in solutions B and C). Larger boards and board committees have a broader skillset, which can aid decision making.

However, results partially support the concept that different combinations of governance factors lead to strong financial performance because in solution A the attribute board size is not present. Therefore, solution A confirms what Hermalin and Weisbach (2003) stated: a large board may impair firm performance.

According to previous steps of analysis (Ossola et al., 2015, 2018), the number of low-cost passengers should have a direct correlation with the EBITDA and should therefore benefit the financial performance. This study instead partially confirms Proposition 2. In solution $C$ the attribute is not relevant, thus confirming previous quantitative analysis (Oum et al., 2003). This is due to the particular importance that nonaviation activities have on some air management companies where air transport is represented by both traditional and low-cost vectors.

Regarding the causal effect of employment rate on performance, this study confirms Proposition 6, the higher the number of employees, the higher the financial performance (Ossola et al., 2018; Oum et al., 2003).

Consequently, the research model emphasizes the importance of the profitability per each employee and the fact that the employment level in the local territory in which the airport operates is fundamental for the survival of air management companies. Indirectly, this result underlines that a high level of employment also impacts the value creation of the company and of the local territory by producing positive externalities.

\section{Conclusion, Limitations, and Future Developments of the Study}

This research represents the second step of a larger research project on the topic of low-cost air transport. This article represents a multidisciplinary study as the interest towards the development of low-cost airlines has important consequences and enhances the relationship with the territory in which air management companies operate.

The other original aspect of this research lies in the methodological approach, with no previous work considering the effects of the attributes considered in this study.

The authors' goal was to complement existing literature by clarifying the impact and causal relationship between number of passengers, number of employees, type of revenues, and governance mechanisms on the overall financial performance (ROA).

The core causal condition, aviation revenues, directly influences financial performance in all solutions. Interestingly, nonaviation revenues were a determinant factor only in solution B. Related to this aspect, solution $\mathrm{C}$ is the only one where the number of passengers is uninfluential, thus showing contradicting results if we consider that aviation activities are relevant in this combination.

Board size and gender are relevant and directly impact financial performance in solution $B$ and C. The presence of affiliated directors instead is a peripheral condition that only affects solution A.

All solutions confirm the relationship between the numbers of employees the air management companies have and their financial performance. Consequently, this result shows that a high level of employment also impacts on the value creation of the company and of the local territory with positive externalities.

These results encourage the use of fsQCA for corporate governance and performance-related research offering novel insights. In this study, authors used governance factors adopted by other researchers (Felício et al., 2016) to test the same approach to the specific context of air management companies in Italy.

Given the exploratory nature of this research, one of the limits is represented by the comparison of financial statements prepared according with different accounting principles. In addition, results show that there can be other combinations explaining the outcome. Therefore, it could be interesting to find some other variables impacting on the financial performance of air management companies. To 
provide additional value to the results, the analysis should extend to other accounting periods.

Further research opportunities remain. These include enlarging the sample size and applying fsQCA to other financial and governance variables. Furthermore, a comparison of air management companies across multiple countries would provide additional insights.

Within the context of the existing literature, this research also has practical implications for managers of air management companies and professionals. They can better identify and analyze the items that directly or indirectly impact on the financial performance of their companies, thus enhancing the value creation of such entities and leading to positive externalities to the local territory in which the company operates. These also have implications for investors and financial institutions during their due diligence processes.

\section{Notes}

${ }^{1}$ Equifinality is in sharp contrast to the unifinal perspective of many statistical techniques, among them the usually applied additive and linear regression models. Equifinality indicates that the same result can be obtained through multiple paths (there is not a unique cause). The concept of asymmetric causality is also important when evaluating the potential of QCA for social science research. Many social science phenomena are the result of asymmetric causal processes and conditions. This means that the explanation of the presence of a phenomenon does not imply that this explanation automatically also accounts for the absence of the same phenomenon. QCA is ready for such a thinking. Different to most statistical procedures, which are based on correlation measures and which assume a symmetric relation between the correlated variables, QCA links conditions and the outcome through set-theoretical and asymmetric relations.

${ }^{2}$ The solution coverage indicates how much is covered by the solution term; raw coverage shows which share of the outcome is explained also by a certain alternative path; and unique coverage indicates which share of the outcome is exclusively explained by a certain alternative path (Ragin, 2006). The consistency instead assesses the degree of perfection of a relationship among sets.

\section{References}

Ahn, T.-H., \& Lee, T. J. (2011). Service quality in the airline industry: Comparison between traditional and low-cost airlines. Tourism Analysis, 16(5), 535-542.

Alazzani, A., Hassanein, A., \& Al-Janadi, Y. (2017). Impact of gender diversity on social and environmental performance evidence from Malaysia. Corporate Governance International Journal of Business in Society, 17(2), 266-283.

Alfiero, S., Cane, M., Esposito, A., \& Doronzo, R. (2018). Determining characteristics of boards adopting integrated reporting. Financial Reporting, 2, 1-46.

Alfiero, S., Cane, M., De Bernardi, P., \& Venuti, F. (2016). Does board gender diversity affect corporate reputation? Evidence from Italy's most reputable companies. World Journal of Management, 7(1), 141-151.

Ashford, N. J., Mumayiz, S., \&Wright, P. H. (2011). Airport engineering: Planning, design and development of 21st century airports. Hoboken, NJ: John Wiley \& Sons.

Boone, C., \& Hendriks, W. (2009). Top management team diversity and firm performance: Moderators of functional-background and locus-of-control diversity. Management Science, 55(2), 165-180.

Brueckner, J. K. (2003). Airline traffic and urban economic development. Urban Studies, 40, 1455-1469.

Bruni, M. (2004). Strategie nel settore aeroportuale. Milano, Italy: Egea Milano.

Button, K., \& Taylor, S. (2000), International air transportation and economic development. Journal of Air Transport Management, 6, 209-222.

Cooper, A., \& Smith, P. (2005). The economic catalytic effect of air transport in Europe. Bretigny-sur-Orge, France: Eurocontrol Experimental Centre.

Cooper, B., \& Glaesser, J. (2015). Analysing necessity sufficiency with qualitative comparative analysis: How do results vary as case weights change? Quality \& Quantity, $1-20$.

Crilly, D., Zollo, M., \& Hansen, M. T. (2012). Faking it or muddling through? Understanding decoupling in response to stakeholder pressures, Academy of Management Journal, 55(6), 1429-1448.

Curi, C., Gitto, S., \& Mancuso, P. (2010). The Italian airport industry in transition: A performance analysis. Journal of Air Transport Management, 16(4), 218-221.

Dalton, D. R., Daily, C. M., Johnson, J. L., \& Ellstrand, A. E. (1999). Number of directors and financial performance: A meta-analysis. Academy of Management Journal, 42, 674-686.

Dogru, T., Bulut, U., \& Sirakaya-Turk, E. (2016). Theory of vulnerability and remarkable resilience of tourism demand to climate change: Evidence from the Mediterranean Basin. Tourism Analysis, 21(6), 645-660.

Dogru, T., Sirakaya-Turk, E., \& Crouch, G. I. (2017). Remodeling international tourism demand: Old theory and new evidence. Tourism Management, 60, 47-55.

Ekinci, Y., Sirakaya-Turk, E., \& Baloglu, S. (2007). Host image and destination personality. Tourism Analysis, 12(5-6), 433-446.

Felício, J. A., Rodrigues, R., \& Samaiago, A. (2016). Corporate governance and the performance of commercial banks: A fuzzy set QCA approach. Journal of Small Business Strategy, 26(1), 87-101.

Finegold, D., Benson, G., \& Hecht, D. (2007). Corporate boards and company performance: Review of research 
in light of recent reforms. Corporate Governance: $A n$ International Review, 15(5), 865-878.

Fiss, P. C. (2011). Building better causal theories: A fuzzy set approach to typologies in organization research. Academy of Management Journal, 54(2), 393-420.

Forsyth, P. (2002). Privatization and regulation of Australian and New Zealand airports. Journal of Air Transport Management, 8, 19-28.

Freeman, R. E. (1984). Strategic management: A stakeholder approach. New York, NY: Cambridge University Press.

Gambel, E. L. (2005). La statistica per la gestione d'impresa. Milano, Italy: FrancoAngeli.

Giacosa, E., \& Giovando, G. (2018). Italian tourism sector as an example of entrepreneurship and growth for companies. In Handbook of research on entrepreneurial ecosystems and social dynamics in a globalized world (pp. 313-331). Hershey, PA: IGI Global Publisher.

Gilbert, J. A., \& Ivancevich, J. M. (2000). Valuing diversity: A tale of two organizations. The Academy of Management Executive, 14(1), 93-105.

Gillen, D. (2011). The evolution of airport ownership and governance. Journal of Air Transport Management, 17(2011), 3-13.

Gitto, S., \& Mancuso, S. (2012). Two faces of airport business: A non-parametric analysis of the Italian airport industry. Journal of Air Transport Management, 20, 39-42.

Graham, A. (2008). Managing airports-An international perspective (3rd ed.). Oxford, UK: Butterworth Heinemann.

Greckhamer, T., Misangyi, V. F., Elms, H., \& Lacey, R. (2008). Using qualitative comparative analysis in strategic management research: An examination of combinations of industry, corporate, and business-unit effects. Organizational Research Methods, 11(4), 1-32.

Grove, H., Patelli, L., Victoravich, L. M., \& Xu, P. (2011). Corporate governance and performance in the wake of the financial crisis: Evidence from U.S. commercial banks. Corporate Governance: An International Review, 19(5), 418-436.

Hermalin, B. E., \& Weisbach, M. S. (2003). Boards of directors as an endogenously determined institution: A survey of the economic literature. Economic Policy Review, 9, 7-26.

Iannotta, M., Gatti, M., \& Huse, M. (2015). Institutional complementaries and gender diversity on boards: A configuration approach. Corporate Governance: An International Review, 24(4), 406-427.

Jensen, J. C. (1993). The modern industrial revolution, exit, and the failure of internal control systems. Journal of Finance, 48, 1-80.

Kasarda, J. (2006). The new business model. Global Airport Cities, 8-13.

Kleymann, B., \& Seristo, H. (2004). Managing strategic airline alliances. Aldershot, UK: Ashgate.

Kravitz, D. A. (2003). More women in the workplace: Is there a payoff in firm performance? The Academy of Management Executive, 17(3), 148-149.
Lai, P.-L., Potter, A., \& Beynon, M. (2012). The development of benchmarking techniques in airport performance evaluation research. Transportation Journal, 51(3), 305-337.

Landry, E. E., Bernardi, R. A., \& Bosco, S. M. (2014). Recognition for sustained corporate social responsibility: Female directors make a difference. Corporate Social Responsibility and Environmental Management, 23(1), 27-36.

La Porta, R., Lopez-de-Silanes, F., Shleifer, A., \& Vishny, R. W. (2000). Agency problems and dividend policies around the world. Journal of Finance, 55(1), 1-33.

Larcker, D. F., Richardson, S. A., \& Tuna, I. (2007). Corporate governance, accounting outcomes, and organizational performance. The Accounting Review, 82, 963-1008.

Liao, L., Luo, L., \& Tang Q. (2015). Gender diversity, board independence, environmental committee and greenhouse gas disclosure. The British Accounting Review, 47(4), 409-424.

Morrell, P. (2008). Can long-haul low-cost airlines be successful? Research in Transportation Economics, 24(1), 61-67.

Morrison, S. A., \& Winston, C. (1995). The evolution of the airline industry. Washington, DC: Brookings Institution.

Oliveira Cruz, C., \& Sarmento, J. M. (2017). Airport privatization with public finances under stress: An analysis of government and investor's motivations. Journal of Air Transport Management, 62, 197-203.

Ossola, G., Giovando, G., \& Crovini, C. (2015). Traffico passeggeri low-cost: impatto sul fatturato e sul risultato d'esercizio delle imprese di gestione aeroportuale. Management delle Infrastrutture e delle Utilities, 2(2015), $12-22$.

Ossola, G., Giovando, G., Crovini, C. (2016). New strategies in Italian airports. In D. Vrontis, S. Bresciani, \& M. Rossi (Eds.), Managing globalization: New business models, strategies and innovation (pp. 1-24). Newcastle, UK: Cambridge Scholars Publishing.

Ossola, G., Giovando, G., \& Crovini, C. (2018). The development of low-cost air transport: Performance, valuecreation and employment of air management companies. In Smart tourism (pp. 249-264). Milan, Italy: McGrawHill Education.

Oum, T. H., Yan, J., \& Yu, C., (2008). Ownership forms matter for airport efficiency: A stochastic frontier investigation of worldwide airports. Journal of Urban Economics, 64(2), 422-435.

Oum, T. H., Yu, C., \& Fu, X. (2003). A comparative analysis of productivity performance of the world's major airports: Summary report of the ATRS global airport benchmarking research report-2002. Journal of Air Transport Management, 9(5), 285-297.

Pajunen, K. (2008). Institutions and inflows of foreign direct investment: A fuzzy-set analysis. Journal of International Business Studies, 39(4), 652-669.

Poveda, A. C., \& Martínez, C. I. P. (2013). Qualitative comparative analysis (QCA): An application for the industry. Quality \& Quantity, 47, 1315-1321. 
Pulina, M., \& Cortés-Jiménez, I. (2010). Have low-cost carriers influenced tourism demand and supply? The case of Alghero, Italy. Tourism Analysis, 15(6), 617-635.

Ragin, C. C. (1987). The comparative method: Moving beyond qualitative and quantitative strategies. Berkeley, CA: University of California Press.

Ragin, C. C. (2000). Fuzzy-set social science. Chicago, IL: University of Chicago Press.

Ragin, C. C. (2006). Set relations in social research: Evaluating their consistency and coverage. Political Analysis, 14(3), 291-310.

Ragin, C. C. (2008). Redesigning social inquiry: Fuzzy sets and beyond. Chicago, IL: University of Chicago Press.

Ragin, C. C., \& Fiss, P. C. (2008). Net effects analysis versus configurational analysis: An empirical demonstration. In Redesigning social inquiry: Fuzzy sets and beyond (pp. 190-212). Chicago, IL: University of Chicago Press.

Ray, D. M. (2005). Corporate boards and corporate democracy. Journal of Corporate Citizenship, 20, 93-105.

Renders, A., \& Gaeremynck, A. (2012). Corporate governance, principal-principal agency conflicts, and firm value in European listed companies. Corporate Governance: An International Review, 20(2), 125-143.

Ricciardi, F., Zardini, A., \& Rossignoli, C. (2018). Business network commons and their fragilities: Emerging configurations of local organizational fields. Journal of Business Research, 89, 328-335.

Rihoux, B., \& Ragin, C. C. (2008). Configurational comparative methods: Qualitative comparative analysis (QCA) and related techniques. Thousand Oaks, CA: Sage Publications

Rohwer G. (2011). Qualitative comparative analysis: a discussion of interpretations. European Sociological Review, 27(6), 728-740.

Romero, J., Lafont, J., Tafur, J., \& Eguren, S. (2016). Performance and value creation at United Kingdom's airports using fsQCA. Journal of Business Research, 69, 1442-1445.

Sanan, N. K. (2016). Board gender diversity and firm performance: Evidence from India. Asian Journal of Business Ethics, 5(1-2), 1-18.
Seierstad, C., Warner-Søderholm, G., Torchia, M., \& Huse, M. (2017). Increasing the number of women on boards: The role of actors and processes. Journal of Business Ethics, 141(2), 289-315.

Shearman, P. (1992). Air transport: Strategic issues in planning and development. London, UK: Pitman Publishing.

Spiegel, M. R. (1994). Statistica. Milano, Italy: McGrawHill.

Teodori, C., Carini, C., \& Falini, A. (2006). L'analisi di bilancio delle imprese di gestione aeroportuale. In M. Martellini (Ed.), Economia e gestione delle imprese aeroportuali. Milano, Italy: Franco Angeli.

Thelle, M. H., \& la Cour Sonne, M. (2018). Airport competition in Europe. Journal of Air Transport Management, 67(2018), 232-240.

Tsekeris, T. (2011). Greek airports: Efficiency measurement and analysis of determinants, Journal of Air Transport Management, 17, 140-142.

Tyrrell, T. J., \& Johnston, R. J. (2002). Estimating regional visitor numbers. Tourism Analysis, 7(1), 33-41.

Usami, M., \& Akai, N. (2012). Financial performance of airport terminal companies in Japan-Harmful effects of government participation. Journal of Air Transport Management, 25, 40-43.

Van Essen, M., Engelen, P. J., \& Carney, M. (2013). Does "good" corporate governance help in a crisis? The impact of country- and firm-level governance mechanisms in the European financial crisis. Corporate Governance: An International Review, 21(3), 201-224.

Vogel, H.-A. (2006). Airport privatisation: Ownership structure and financial performance of European commercial airports. Competition and Regulation in Network Industries, 1(2), 139-162.

Wang, W.-K., Lu, W.-M., \& Tsai, C-J. (2011). The relationship between airline performance and corporate governance amongst US listed companies. Journal of Air Transport Management, 17, 148-152.

Woodside, A. G. (2010). Case study research: Theory, methods and practice. London, UK: Emerald.

Zhong, Y. S., Busser, J., \& Baloglu, S. (2017). A model of memorable tourism experience: The effects on satisfaction, affective commitment, and storytelling. Tourism Analysis, 22(2), 201-217. 